\title{
Pemberdayaan ekonomi kreatif masyarakat melalui pelatihan pembuatan dendeng udang di Desa Sungsang II, Banyuasin II
}

\section{Herpandi, Sherly Ridhowati ${ }^{\star}$, Rodiana Nopianti, Shanti Dwita Lestari, \& Indah Widiastuti}

\author{
Universitas Sriwijaya, Indonesia
}

*sherlyridhowati@unsri.ac.id

\begin{abstract}
Sungsang II Village, Banyuasin II is an area where the livelihoods of the community are dominant as fishermen and entrepreneurs, namely trading food products. Their seafood varies, as well as their processed products. However, their well-known superior product is shrimp-based food products, especially Penaeus vannamei shrimp, abundant and non-economical. The opportunity for this service is one of the efforts to empower the community's creative economy, as hard as with the silvo-fishery programs. The method have used in this service activity, likely discourse and direct-practice, the evaluation of this achievement was using achievement measurement tools. In concluded that the achievement score was $96 \%$ based on the average test score. This training have provided to the community through community service programs could be an effort to empower the community in seeing the opportunities in existing resources for economic activities.
\end{abstract}

\begin{abstract}
Abstrak Desa Sungsang II, Banyuasin II merupakan daerah yang mata pencaharian masyarakatnya dominan sebagai nelayan dan wiraswasta yaitu berdagang produk makanan. Hasil laut yang mereka peroleh beranekaragam, begitu juga hasil olahannya. Namun, produk unggulan mereka yang terkenal adalah produk makanan berbasis udang, khususnya udang peci (Penaeus vannamei), melimpah dan non ekonomis. Peluang ketersediaan ini sebagai salah satu usaha pemberdayaan ekonomi kreaktif masyarakat, selaras dengan program yang dituju yaitu pengolahan hasil perikanan silvo-fisheries. Metode yang digunakan pada kegiatan pengabdian ini berupa metode ceramah dan praktek langsung, serta dilakukan evaluasi capaian kegiatan dengan menggunakan alat ukur ketercapaian. Secara keseluruhan ketercapaian program ini berhasil dengan nilai ketercapaian sebesar $96 \%$ berdasarkan rerata nilai test. Pelatihan yang diberikan kepada masyarakat melalui program pengabdian dapat menjadi usaha pemberdayaan masyarakat dalam melihat peluang ketersediaan sumber daya yang ada untuk aktivitas ekonomi.
\end{abstract}

Keywords: jerky; creative economy; shrimp; Sungsang village

\section{¿ OPEN ACCESS}

Citation: Herpandi., S. Ridhowati., R. Nopianti., S. D. Lestari., \& I. Widiastuti. (2021). Pemberdayaan ekonomi kreatif masyarakat melalui pelatihan pembuatan dendeng udang di Desa Sungsang II, Banyuasin II. Riau Journal of Empowerment, 4(1), 21-28. https://doi.org/10.31258/raje.4.1.21-28

Received: 2021-03-24 Revised: 2021-04-14 Accepted: 2020-04-21

Language: Bahasa Indonesia (id)

Funding: DIPA Universitas Sriwijaya

ISSN 2623-1549 (online), 2654-4520 (print)

C 2021 Herpandi, Sherly Ridhowati*, Rodiana Nopianti, Shanti Dwita Lestari, \& Indah Widiastuti. Author(s) retain the copyright of article published in this journal, with first publication rights granted to Riau Journal of Empowerment. The article is licenced under Creative Commons Attribution 4.0 Internationa License. This license permits unrestricted use, distribution, and reproduction in any medium, provided the original author and source are credited. 


\section{PENDAHULUAN}

Desa di daerah Sungsang terdiri dari Desa Sungsang I sampai IV, Kecamatan Banyuasin II, Banyuasin merupakan daerah yang mata pencaharian masyarakatnya dominan sebagai nelayan dan wiraswasta yaitu berdagang produk makanan. Hasil laut yang mereka peroleh saat laut pasang berupa berbagai jenis ikan laut, ikan air tawar, udang, kepiting, rajungan, cumi-cumi, dan sebagainya. Produk makanan yang dominan mereka jual adalah pempek, tekwan dan kerupuk kemplang. Produk makanan tersebut yang dijual maupun dikonsumsi sendiri merupakan panganan yang berbasis ikan atau udang, namun produk unggulan mereka yang terkenal adalah produk makanan berbasis udang, khususnya udang peci (Penaeus vannamei). Semua produk itu merupakan jenis produk olahan tradisional. Daerah Banyuasin memiliki potensi untuk dikembangkan menjadi sentra perikanan baik perikanan budi daya, penangkapan dan usaha pengolahan dari perikanan budidaya dan penangkapan. Selain itu, Banyuasin potensial untuk pengembangan produk perikanan dan kelautan karena sebagian besar berupa dataran rendah pesisir dan muara sungai.

Salah satu program yang dituju adalah pengolahan hasil perikanan silvo-fisheries sebagai usaha pemberdayaan ekonomi kreaktif. Salah satu produk olahan yang bisa diterapkan yaitu pembuatan dendeng tiruan dari udang dikarenakan bahan dasar yang digunakan sangat berlimpah, tidak terpengaruh musim, dan masyarakat daerah Sungsang terkenal dengan pangan olahan dari bahan dasar ini. Pembuatan dendeng tiruan dapat menambah variasi hasil olahan berbahan dasar udang, dan sumber pangan olahan yang bergizi ketika musim kemarau untuk masyarakat Desa Sungsang II. Febrina (2012) menuliskan bahwa kualitas dendeng sangat dipengaruhi oleh tingkat ketebalannya. Pemilihan kualitas olahan dipengaruhi oleh bahan dasar terutama daging dengan daya ikat air yang tinggi. Pembuatan dendeng tiruan dapat menambah variasi hasil olahan berbahan dasar udang. Tepung tapioka adalah bahan pengikat dengan karakteristik yang mampu meningkatkan stabilitas emulsi, daya ikat air, flavor, karakteristik irisan produk, serta mengurangi pengerutan selama pemasakan, dan biaya formulasi (Garnida et al., 2015). Penelitian dari El Husna et al. (2014) dan Ashlan et al. (2011) tentang dendeng ikan, dendeng ayam (Singh et al., 2001), sedangkan untuk dendeng udang peci belum ada, baru sebatas penambahan produk fermentasi dari udang dan ikan teri sebagai bahan curing pada dendeng sapi (Kim et al., 2014). Sehingga, pengolahan udang menjadi salah satu bahan pembuatan dendeng diharapkan dapat menjadi produk diversifikasi makanan yang bergizi tinggi dan sebagai salah satu upaya pemberdayaan ekonomi masyarakat Sungsang kreatif, menitikberatkan pada kaum wanita.

\section{METODE PENERAPAN}

Metode yang digunakan berupa metode ceramah dan praktek langsung, serta dilakukan evaluasi capaian kegiatan dengan menggunakan alat ukur ketercapaian. Pada kegiatan pengabdian tahun ini yang menjadi target sebagai peserta adalah kaum wanita nelayan usia produktif maupun tidak produktif, minimal 25 sampai 30 peserta.

\section{Langkah-langkah kegiatan}

Pertama, metode ceramah yang di sampaikan oleh tim pengabdian secara bergantian sesuai dengan pembagian tugas yang telah disepakati. Materi yang disampaikan mulai dari bagaimana cara memberdayakan masyarakat khususnya para wanita untuk meningkatkan 
pendapatan melalui sumber daya alam yang melimpah, apa yang dimaksud dengan dendeng udang, dan bagaimana cara membuat dan mengolah dendeng udang. Penyampaian konsepkonsep ini dalam bentuk materi PowerPoint dengan memanfaatkan laptop dan LCD.

Kedua, praktek pembuatan dendeng udang yang melibatkan 10 orang mahasiswa

Teknologi Hasil Perikanan Universitas Sriwijaya (UNSRI) tahun 2014. Para mahasiswa tersebut juga membantu proses monitoring saat Tim Pengabdian turun ke lapangan.

\section{Cara Membuat Dendeng Udang}

Pada prinsipnya, proses pembuatan dendeng tiruan dari udang peci (Penaeus vannamei). yaitu semua bagian daging dari udang, kecuali kotoran, kulit, digunakan dalam proses pembuatan dendeng. Daging udang digiling sebanyak 500 Gram baru kemudian ditambahkan bumbubumbu (garam, gula merah, bawang putih, bawang merah, lada), ikan teri yang telah dihaluskan. Semua bahan tersebut diaduk sampai rata, baru kemudian ditambahkan tepung tapioka (50 gram) sebagai pengisi sedikit demi sedikit sambil diaduk secara merata. Kemudian, adonan tersebut dicetak seperti lembaran-lembaran dengan ketebalan $\pm 3 \mathrm{~mm}$ menggunakan roller. Lembaran-lembaran dendeng tersebut baru dijemur dibawah terik sinar matahari, setelah itu lembaran dendeng dapat disimpan sampai waktu konsumsi sesuai kebutuhan, cara konsumsi bisa langsung diolah dengan bumbu masak atau langsung digoreng .

\section{Alat Ukur Ketercapaian}

Evaluasi kegiatan sangat diperlukan untuk menentukan keberhasilan dalam pencapaian tujuan kegiatan pengabdian ini. Evaluasi dilakukan dalam dua pola. Pertama, evaluasi sebelum pelaksanaan pengabdian (pre-test) untuk menentukan skor dasar (base score). Kedua, evaluasi sesudah pelaksanaan pengabdian (post-test) untuk menentukan peningkatan pengetahuan masyarakat. Pre-test dan post-test yang akan diadakan dalam bentuk kuesioner. Pertanyaan kuesioner menitikberatkan pada penguasaan materi dan keterampilan mulai dari udang peci, cara pembuatan dendeng, sampai keinginan untuk diversifikasi produk dendeng bernilai ekonomis. Hasil selisih antara pre-test dengan post-test diketahui sebagai parameter akhir keberhasilan pelaksanaan pengabdian.

\section{HASIL DAN KETERCAPAIAN SASARAN}

Udang, khususnya udang peci, hasil tangkapan nelayan yang melimpah terutama musim kemarau (musim laut surut), selalu tersedia dan biasanya dijual dengan harga yang sangat murah karena udang tersebut hanya dijual dalam bentuk utuh, udang atau ikan spesies tertentu langsung dijual dan tidak diolah menjadi produk makanan karena bernilai jual tinggi. Salah satu produk yang dapat memanfaatkan udang adalah dendeng tiruan. Dendeng tiruan merupakan produk olahan modern akan tetapi proses pembuatannya sederhana sehingga mudah untuk diaplikasikan di masyarakat. Selain itu, dendeng tiruan dari udang dapat menambah varian produk olahan dan meningkatkan konsumsi gizi, serta keterampilan masyarakat di Desa Sungsang II Kecamatan Banyuasin II, Banyuasin. Peningkatan keterampilan masyarakat sebagai usaha pemberdayaan masyarakat khususnya di bidang ekonomi melalui diversifikasi makanan dapat meningkatkan nilai tambah udang dan pendapatan masyarakat. 
Kegiatan ini dihadiri oleh para wanita nelayan baik muda mapun tua sebanyak 50 peserta. Para wanita yang menjadi peserta pelatihan pengabdian tahun lalu, terlebih dahulu mereka melakukan registrasi sebagai peserta. Kegiatan ini dibuka oleh ketua tim pengabdian masyarakat, lalu kegiatan dilanjut kata sambutan yang diwakili oleh ketua wanita nelayan. Kepala desa sangat mendukung kegiatan yang dilaksanakan oleh Unsri untuk desa yang dipimpinnya. Berdasarkan pernyataan dari ketua wanita nelayan, bahwa desa Sungsang II memang sangat terkenal dengan olahan hasil dari udang yang sangat melimpah di daerah sungsang ini. Sumber bahan tersebut terkadang menoton alias belum ada inovasi untuk produk baru, bahkan sering kali tidak termanfaatkan dikarenakan nilai jual rendah. Kegiatan pembukaan dan pelatihan pembuatan dendeng yang dilaksanakan dapat dilihat pada Gambar 1.

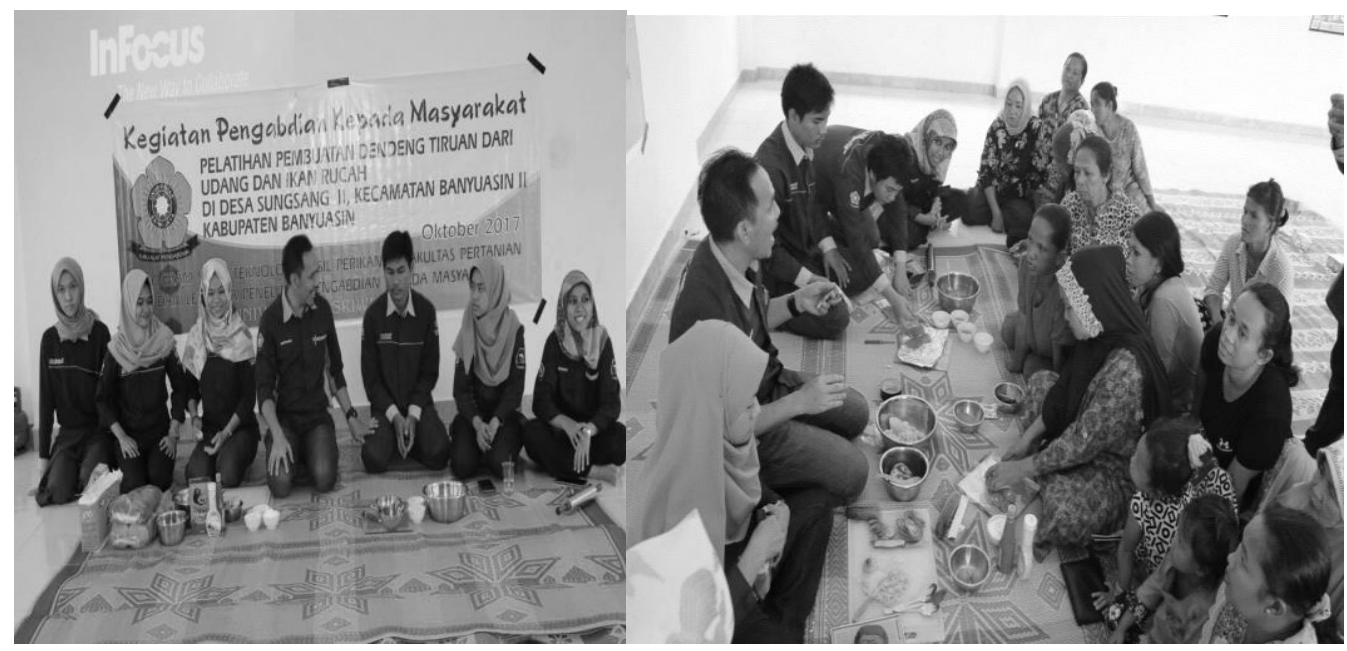

A

B

Gambar 1. Pembukaan kegiatan pengabdian masyarakat tentang pelatihan pembuatan dendeng udang (A); Penyampaian materi dan praktek pembuatan dendeng udang (B).

Kegiatan pengabdian ini diharapkan sebagai pengetahuan penambah wawasan bagi para wanita nelayan untuk memanfaatkan udang menjadi produk pangan bergizi tinggi, selain dapat memenuhi kebutuhan gizi serta dapat meningkatkan nilai jual daripada udang sehingga pendapatan keluarga nelayan bertambah. Kegiatan ini sendiri dibagi menjadi dua sesi, yaitu penjelasan dan demo pembuatan dendeng dari udang. Penyampaian materi secara menyeluruh disampaikan oleh ketua pelaksana, untuk bagian demo pembuatan dijelaskan dan dilakukan oleh mahasiswa program studi Teknologi Hasil Perikanan, Fakultas Pertanian, Unsri. Para wanita nelayan pun tak lupa antusias untuk ikut praktek membuat dendeng dari kedua bahan tersebut (Gambar 1).

Tahapan pertama dari kegiatan demo yaitu demo pembuatan dendeng dari udang (Gambar 2 dan 3). Warga desa sungsang II sangat antusias dengan tema yang diberikan dalam pengabdian ini. Dengan tema kali ini memberitahukan kepada warga desa bahwa dendeng bisa juga dibuat dari bahan lain selain daging sapi (Suryati et al., 2014), daging ayam (Singh et al., 2001; Zhuang et al., 2007), yaitu udang, dengan kata lain diversifikasi konsumsi pangan. 

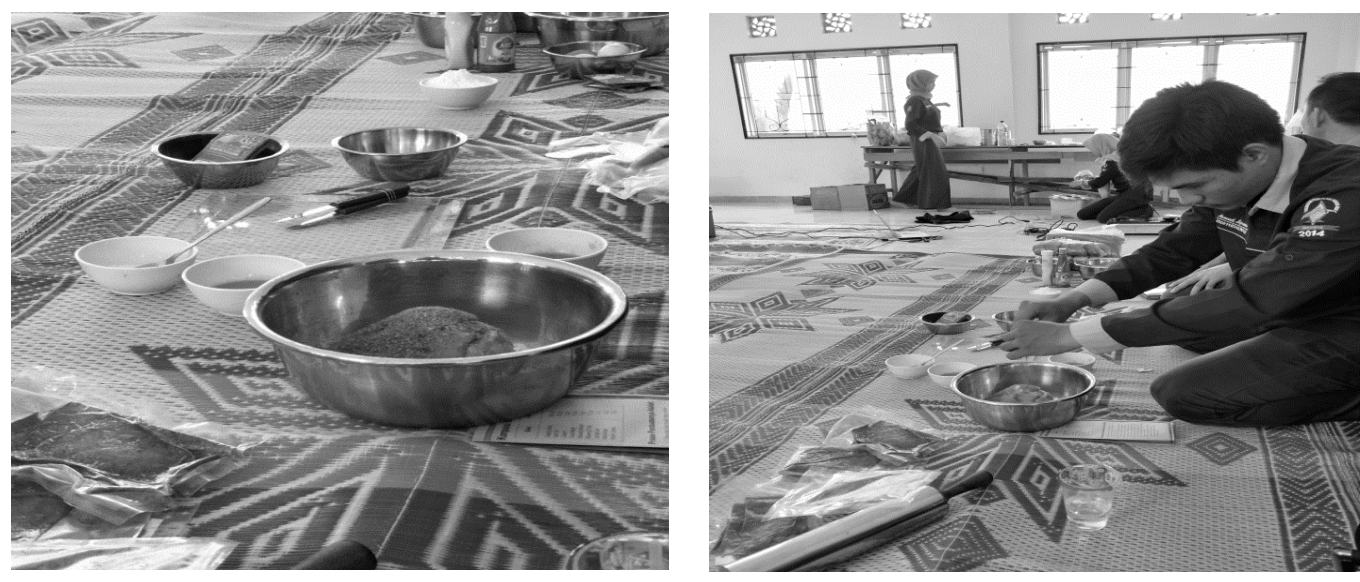

Herpandi et al.

Gambar 2. Proses pembuatan dendeng dari udang

Sikap antusias dan ketertarikan para wanita nelayan terlihat pada banyaknya pertanyaan dan keikutsertaan mereka dalam proses pembuatan dendeng. Mereka juga baru tahu kalau dendeng tidak hanya dibuat dari daging sapi tetapi bisa juga dari udang, sehingga tidak memerlukan biaya investasi besar. Kedua produk tersebut malah dapat dijadikan sebagai salah satu solusi ketika panen udang dalam jumlah yang melimpah, kesulitan dalam penanganan, murahnya harga ikan rucah di pasaran, serta variasi konsumsi udang yang dapat dijadikan sebagai sumber lauk-pauk.
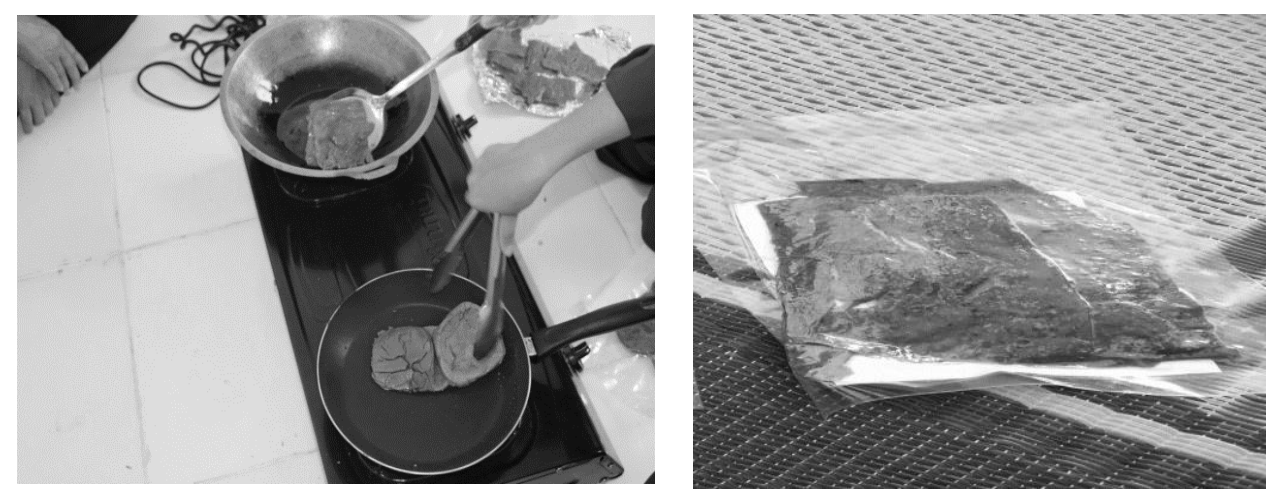

Gambar 3. Proses penggorengan dan produk dendeng yang telah jadi

Berdasarkan Gambar 3. terlihat perbedaan warna produk akhir dendeng, warna produk coklat kemerahan) setelah adonan dibentuk lembaran dendeng dipengaruhi oleh jenis bahan utama yaitu daging udang, ada tidaknya penambahan ikan teri, bumbu-bumbu sebagai penyedap dan humektan, serta tepung tapioka (Singh et al., 2001; Zhuang et al., 2007; Suryati et al., 2014). Pada pengabdian ini, produk dendeng tiruan dari udang peci. Untuk memaksimalkan potensi udang jenis non ekonomis ini dilakukan usaha pengolahan, salah satunya pembuatan dendeng, agar diperoleh nilai tambah. Pengolahan daging udang menjadi dendeng, hal ini didasarkan pada beberapa metode pengolahan dendeng, bahan dan peralatan yang sederhana dan mudah didapatkan. Untuk menambah aroma dendeng udang agar disukai, salah satunya dapat dilakukan dengan menambahkan rempah-rempah. Bumbu dasar umumnya yang digunakan untuk membuat dendeng, yaitu garam 3\%, gula merah $30 \%$, ketumbar $2 \%$, bawang putih $1.5 \%$, bawang merah 3\%, asam 1\%, dan asam sendawa 5\% (Dewi et al., 2019). 
Penelitian terbaru dari Suryati et al. (2014) meneliti tentang pembuatan dendeng dengan cara memodifikasi formulasi rempah-rempah dendeng, teknik penggaraman (curing), dan precooking, mampu mengurangi kadar residu nitrit dan malonaldehida (MDA). Kim et al. (2014) mengolah dendeng sapi dengan cara menambahkan produk fermentasi udang dan ikan teri sebagai bahan curing dendeng. Hasilnya menunjukkan bahwa bahan curing dari udang fermentasi pada dendeng sapi merupakan good ingredient, walaupun curing dari ikan teri dapat meningkatkan karakteristik sensoris dan tekstur. Kualitas sensoris panelis juga meningkat untuk penambahan daging ikan lele pada dendeng daun singkong, selain itu kadar proteinnya juga meningkat antara $25.9 \%$ sampai 30.8\% (Ismanto et al., 2015). Selain untuk diversifikasi produk berbasis udang ini sebagai usaha ekonomi kreaktif, dapat juga sebagai untuk konsumsi pangan lauk-pauk, Ridhowati et al. (2019) menyatakan bahwa dendeng udang memiliki $77.61 \%$ protein, $13.37 \%$ karbohidrat, dan $0.32 \%$ lemak

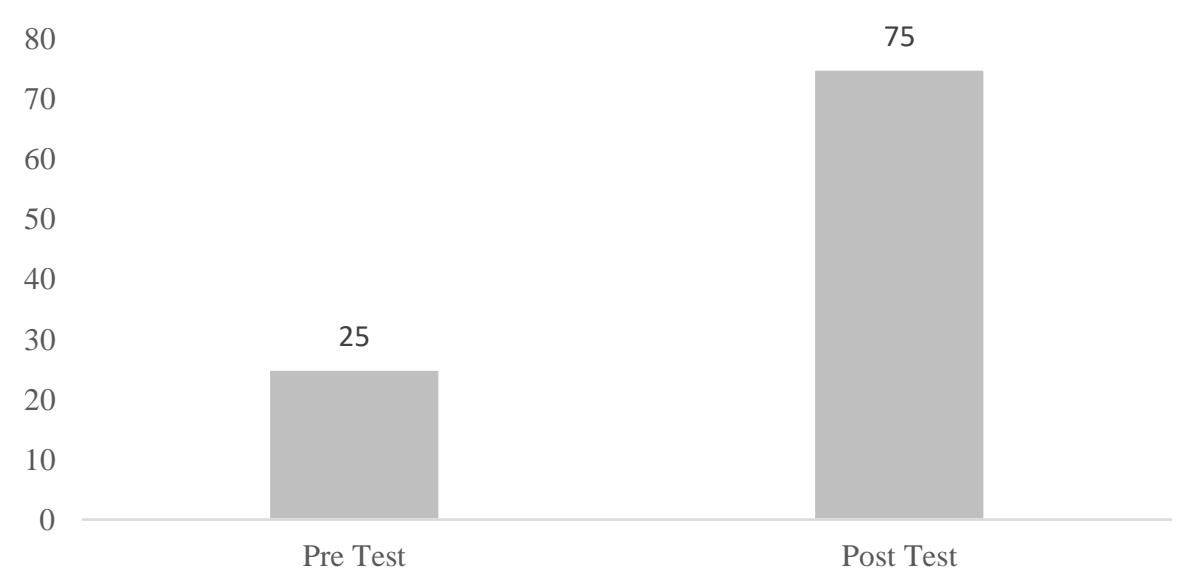

Gambar 4. Rerata nilai pre-test dan post-test pada kegiatan pengabdian

Kegiatan diversifikasi udang menarik terlihat dari sikap antusias dan ketertarikan para wanita nelayan juga didukung oleh data evaluasi, dimana rerata nilai pre-test sebesar $25 \%$, kemudian kegiatan monitoring dilakukan sehingga nilai post-test diperoleh sebesar $75 \%$, dilihat pada Gambar 4. Hasil rerata nilai ini menunjukkan bahwa adanya peningkatan pengetahuan masyarakat tentang dendeng tiruan dari daging udang. Peningkatan hasil test dikarenakan adanya penyampaian pengetahuan atau materi tentang dendeng udang itu sendiri. Kegiatan pengabdian ini merupakan perpanjangan inovasi produk, terutama diversifikasi produk berbasis udang dari hasil penelitian yang dilakukan oleh Ridhowati et al. (2019). Program pengabdian ini memberikan pengaruh positif terhadap pengetahuan dan wawasan masyarakat sebagai peserta sehingga masyarakat sungsang khususnya kaum wanita dapat menambah pendapatan rumah tangga, lebih lanjut bisa bereferk adanya pemberdayaan ekonomi kreatif di desa sungsang II, banyuasin II. Kegiatan pengabdian ini senada dengan Asih \& Fitriani (2018) dan Fauzi et al. (2019), dimana apapun bentuk pelatihan yang diberikan kepada masyarakat melalui program pengabdian sebagai suatu usaha pemberdayaan masyarakat dalam melihat peluang ketersediaan sumber daya yang ada untuk aktivitas ekonomi. Secara keseluruhan ketercapaian program ini berhasil dengan nilai ketercapaian sebesar $96 \%$ dari segi pengetahuan, keterampilan, bahkan keinginan untuk mengembangkan 
usaha pembuatan dendeng berdasarkan rerata nilai test yang diperoleh oleh peserta pengabdian.

\section{KESIMPULAN}

Pembuatan dendeng dari udang prinsipnya sangat sederhana sehingga proses pembuatan produk ini sangat mudah diterima dan diaplikasikan oleh para wanita nelayan desa sungsang II, Banyuasin II. Proses pembuatan dendeng ini tidak memerlukan biaya produksi yang tinggi, sehingga mudah diterapkan sebagai sumber pendapatan, solusi ketika panen udang melimpah, variasi konsumsi sumber lauk-pauk. Pengetahuan akan diversifikasi produk berbasis udang dapat dijadikan sebagai usaha ekonomi kreaktif untuk pemberdayaan masyarakat. Akan tetapi, data pendukung seperti analisa kelayakan ekonomi dan keberlanjutannya perlu dilakukan.

\section{UCAPAN TERIMA KASIH}

Makalah ini merupakan hasil kegiatan pengabdian kepada masyarakat tahun 2018 yang didanai oleh DIPA Universitas Sriwijaya. Kami juga berterima kasih kepada para mahasiswa/i teknologi hasil perikanan angkatan 2014, terkhusus Muhammad Dani dan tim.

\section{Daftar Pustaka}

1. Ashlan, S. O., Michael, P. D., \& Mary, E. C. (2011). Characteristics of formed atlantic salmon jerky. Journal of Food Science, 76(6), 5396-5400. https://doi.org/10.1111/j.1750$\underline{3841.2011 .02245 . \mathrm{x}}$

2. Asih, H. M., \& Fitriani, S. (2018). Penyusunan standard operating procedure (SOP) produksi inovasi ecobrick. Jurnal Ilmiah Teknik Industri, 17(2), 144. https://doi.org/10.23917/jiti.v17i2.6832

3. Dewi, S. H. C., Wariyah, C., \& Astuti, N. (2019). Dendeng of cured duck meat in curcumin extract with added STPP, reviewed from chemical quality. IOP Conference Series: Earth and Environmental Science, 379, 1-4. http://doi.org/10.1088/1755-1315/379/1/012002

4. El Husna, N., Asmawati, \& Gunawan, S. (2014). Dendeng ikan leubiem (Canthidermis maculates) dengan variasi metode pembuatan jenis gula, dan metode pengeringan. Jurnal Teknologi dan Industri Pertanian Indonesia, 6(3), 77-81. http://dx.doi.org/10.17969/jtipi.v6i3.2316

5. Fauzi, M., Eni, S., Adriman., Rusliadi., \& Ika, F. (2019). Pemberdayaan masyarakat melalui pelatihan pembuatan ecobrick sebagai upaya mengurangi sampah plastic di Kecamatan Bunga Raya. Raje Journal of Empowerment, 3(2), 87-96. https://doi.org/10.31258/raje.3.2.87-96

6. Febrina, N. (2012). Tingkat penambahan nanas (Ananas comosus) dan lama penyimpanan terhadap tingkat oksidasi lemak dan perubahan kualitas dendeng giling daging sapi. Skripsi Program Sarjana. Universitas Hasanudin. Makasar.

7. Garnida, Y., Ela, T., \& Jepri, I. (2015). Pengaruh penambahan tepung tapioka dan suhu pengeringan terhadap karakteristik dendeng giling ikan pari (Dasytis sp). Skripsi Program Sarjana. Universitas Pasundan. Bandung.

8. Ismanto, S. D., Surini, S., \& Silvia, N. (2015). Effect of the addition of catfish meat on improving of jerked meat protein from cassava leaves (Manihot utilissima). International Journal on Advanced Science Engineering Information Technology, 5(2). https://doi.org/10.18517/ijaseit.5.2.492

9. Kim, G-D., Go, G-W., Lim, H-J., Jung, E-Y., Seo, H-W., Jeong, J-Y., Joo, S-T., \& Yang, H-S. (2014). Physicochemical characteristics of beef jerky cured with salted-fermented anchovy and 
shrimp. Korean Journal for Food Science of Animal Resources, 34(1), 98-105.

https://doi.org/10.5851/kosfa.2014.34.1.99

10. Ridhowati, S., Lestari, S., Lestari, S. D., \& Sari, D. I. (2019). Physicochemical and sensory properties from Indonesian white shrimp (Penaeus merguiensis). Pertanika Journal of Tropical Agricultural Science, 42(1), 833-845. https://www.cabdirect.org/globalhealth/abstract/20193325758

11. Singh, R. R. B., Rao, K. H., Anjaneyulu, A. S. R., \& Patil, G. R. (2001). Moisture sorption properties of smoked chicken sausages from spent hen meat. Food Research International, 34(12), 143-148. https://doi.org/10.1016/S0963-9969(00)00145-9

12. Suryati, T., Astawan, M., Lioe, H. N., Wresdiyati, T., \& Usmiati, S. (2014). Nitrite residue and malonaldehyde reduction indendeng-Indonesian dried meat-influenced by spices, curing methods and precooking preparation. Meat Science, 96(3), 1403-1408.

https://doi.org/10.1016/j.meatsci.2013.11.023

13. Zhuang, H., Nelson, S. O., Trabelsi, S., \& Savage, E. M. (2007). Dielectric properties of uncooked chicken breast muscle from ten to one thousand eight hundred megahertz. Poultry Science, 86(11), 2433-2440. https://doi.org/10.3382/ps.2006-00434 